THE “OPEN-DOOR" SYSTEM AND THE RISK OF PROSECUTION.

In May last a female patient escaped from the Lenzie Asylum, Glasgow, through an unlocked door, and was killed-whether suicidally or not is unknown-on the railway near the Asylum.

The Public Prosecutor for the County has intimated to the Asylum authorities that if euch an accident occurs again it may be his duty to iustitute an investigation as to whether there has not been culpable negligence in the custody of the lunatic ; and the husband of the deceased woman has, we observe, raised an action against the managers of the Asylum for damages for the loss of his wife. The managers have compromised this action by a payment of $£ 50$ to the husband. A very serious question is thus raised, and one which involves the increase of the already sufficiently heavy risks and anxieties of asylum physicians. We believe that during the last year the number of suicides in Scotch Asylums has been unusually large. Is this a mere coincidence, or is it associated with the granting of a greater amount of liberty ?

CHANGES IN THE LUNACY BOARD.

Early in July Dr. Nairne, who had held the appointment of Commissioner in Lunacy since 1857, resigned his seat at the Board. The vacancy was so quickly filled up that the resignation of Dr. Nairne and the appointment of his successor, Dr. Reginald Southey, of London, were announced at the same time.

We are sure that the best wishes of Dr. Nairne's numerous friends attend him in his retirement from his very protracted term of service.

\title{
Obituary.
}

\section{B. H. EVERTS, M.D.}

Doctor B. H. Everts died at Arnhem, on the 2nd of July, 1883.

He was born in 1810, ard after having passed through a grammar school took his degree at the University of Leyden. His medical studies were interrupted in 1830 by the war with Belgium; he joined the corps of volunteers formed by the Leyden students. After having taken his medical degree he settled at Deventer, and there held the position of Superintendent of the Lunatic Asylum (1844).

The provincial government of North Holland having resolved to build an asylum, Everts was appointed to be Medical Superintendent, and he devoted the time between 1847, while Meerenberg was being built, and 1849, when it was opened, to visiting several foreign asylums.

In England he was greatly interested in the non-restraint system, and it was only natural that his humane nature warmly supported it. The result was that he decided apon introducing it into the Meerenberg Asylum, and thanks to his care this was the first asylum on the Continent of Europe where it was intrcduced. We were much pleased with his asylum in visiting it in 1853

It may be said that he loved his work and his patients, and to his attachment to them, it must be ascribed that he refused a call to Amsterdam where a chair of pathology was offered him.

Dr. Everts resigned his position as Superintendent in 1874, and spent the rest of his days at Arnhem.

In him the profession loses a devoted member.

ROBERT BOYD, M.D. EDIN.

On the 14th of August, 1883, at his Private Asylum, Southall Park, Middlesex, in the fire by which the building was destroyed, Dr. Boyd, aged 75 . Dr. Boyd was the son of Captain William Boyd (South Devon Militia), and 